\title{
AFRICAN MIGRANTS IN SPITE OF "FORTRESS" EUROPE: AN ESSAY IN PHILOSOPHY OF POPULAR CULTURE
}

\author{
Martin F. Asiegbu
}

\section{Introduction}

Africa-to-Europe migration cuts a picture little different from that of the chained slave-driven Africans on their way to Europe, the Americas and the New World. While the forced enslavement spelt doom for the enslaved Africans, their descendants and, indeed, for mother Africa, Africa-to-Europe migration -at the turn of the millennium - seems to be a welcome pack to African immigrants fleeing failed states, poverty, and joblessness. The inability of the European Labor Market to replenish its work force provides African skilled workers an opportunity to take advantage of. While African governments may view Europe's anti-immigration laws and policies in a bad light, for the Europeans, the illegal introduction of Africans into their territory is disruptive of European institutions, social structure and environment. With the exception, sometimes, of the skilled workers, Europe frowns upon refugees, asylum seekers, and the so-called 'economic migrants.' It is surprising, however, that Europe categorizes immigrants into "economic migrants," given her history.

Physical mobility is a feature of the human race. While threat to life, poverty and joblessness, war and persecution, quest for fortunes, etc. may force people to emigrate, no group of people has ever engaged so massively in international migration as did the Europeans. One out of ten Africans has the Irish blood running in his veins. At present, there are at least 40 million Irish residing in the United States of America. One third of the Swedes migrated at difficult times. At present, Swedish government constantly engages in a think-home drive to lure her citizens back into her borders. Between 1800 and 1900, Germans departed their countries in droves in search of greener pastures. Ever since the age of the Enlightenment, the British have not ceased to migrate and settle in foreign lands. Among the colonialists in Africa were those who had no purpose than to make a career in far-flung Africa. And Europe-to- 
Europe 'economic migration' is also very significant. In Britain alone, the number of EU immigrants is alarming insignificant jobs.

While European governments offer African leaders financial support to impede Africa-to-Europe migrants, African governments face the dilemma of providing jobs for millions of their jobless citizens. Hence, unless the root cause of migration - poverty and underdevelopment - is addressed, neither European Union nor African governments will successfully stem the tide of Africa-toEurope migration.

The colonial discourse about the African and economic policies underline the alarmist reports that European media peddle about African migrants. Since the Enlightenment period, the West has perceived Africans as sub-humans. The most eloquent proof of this claim is the long drawn-out slave trade. If there was any subject on which the Europeans were all agreed, it was the enslavement of Africans. Why, one would want to ask, did Europe, for four centuries, give her unalloyed support to the worst heinous act of man's inhumanity to man? The sole meaningful response is that "the Europeans rarely regarded, much less accepted, the Africans as human.... It was a demonstration of the European's (sic) reluctance to recognize the humanity of the African people" (Ogude 1996 in Equiano 1789/1967). For them, the African represented an 'inferior' race to the European race - the ideal of humanity. For their entire sojourn in Africa, the colonialists had a singular goal: to impress this distinctive categorization on the African mind.

Ever since, the African has kept memory of a colonial, imperialist and slave-driving European. Difficult times in Africa demonstrate the extent to which the European colonizer succeeded. The image, which the African cuts of himself, at such times, is one of the inferior,' 'barbarian' in contrast to the 'superior' European. Following the unprecedented economic decline of most African states, Africa-to-Europe migration has redoubled. Nothing betrays the African internalization of the Europeans' jaundiced outlook on Africans as the Europe of the migrants' dream. That such a Europe is a nightmare is a view that African migrants reject to their hurt! 
While noting the sufferings of migrant Africans, the unjust and harsh European immigration laws, the perilous treks through the Sahara desert and the risks of sea-faring to the Canary islands, the Spanish enclaves, etc., this paper seeks to underline the major thesis that Africa-to-Europe migration relives the colonial discourse about the African, initiated since the $15^{\text {th }}$ Century. The idea of a "Fortress" Europe, bandied about as a terrifying symbol of a Europe reluctant to welcome African immigrants, attests to the truth of the principal thesis. It further raises the question, whether Europe need remain Africa's El Dorado?

Within this context, one looks askance at Joseph Winter's reflection on Mamadou Salion "Billy" Diallo. Winter insists that West African youths are hell-bent on migrating to Europe; that they spend their time hatching various plans instead of undertaking other gainful employments. He writes, "Traveling around West Africa, it really is astonishing how many young people have only one goal in life - to leave their home countries" (BBC News Online). Other expressed views similar to Winter's - all furnish low perception of the African.

Interdisciplinary in its outlook, this paper makes much of colonial history and literatures, sociology and philosophy. Equally, it contests the view ascribed to the prize-winning journalist, George Lucky, that Africans are the worse for it since they failed to embrace education, at a time when it afforded them the opportunity of a sojourn in Europe or the United States. The paper espouses the view that African consumer society confers a status symbol on successful immigrants. The image, which Europe forced upon Africa, I shall argue, partly underlies the migrant's conception of Europe as the dreamland, and partly underlies Europe's presentation of herself as a "fortress" against African immigrants. The second part of the paper deals with the migration flows, debunking Lucky's claim about educational opportunities in the colonial era, and finally portraying the profile of an illegal immigrant, typified in the deceased immigrant, Samurah Adamu, and the two Senegalese boys. We commence with the colonial discourse of the African. 


\subsubsection{Part One: Presuppositions: The Tattered Image of the African}

One has only to think of the bulwarks that Europe constructed at her borders to understand that the colonial image of the 'inferior,' 'irrational,' 'barbarian,' - the African - still prevails in the third millennium. Until Africa grows up, becomes developed, and joins the industrialized world, the colonial representation of her will remain. At the height of her modernity pursuits, Europe's interests burdened the African with a characterization that has defaced her since the age of the Enlightenment. The Enlightenment philosophers produced arguments to buttress the popular view about the African. If the rabble with 'little Latin and less Greek' entertained a negative image of the Africa, certainly more baffling was the commitment of influential Enlightenment philosophers like Kant, Hume and Hegel to propagate such an image of the African. These Enlightenment philosophers not only bought into the popular conception of Africa as the 'inferior' and 'sub-human', they provided philosophical arguments to prop up popular negative outlook of the African.

For the philosophers of the Enlightenment, the African was as good as non-existent. He was a sub-human, not merely inferior to the paragon of rationality - the European. Indeed, Montesquieu (1952: 110) drew the consequences of the Enlightenment philosophers' perception of the African: the African was not as yet a human being for the Church to preoccupy herself with saving his/her soul. Since to be saved, one must, first of all, possess a soul. The African had none - no soul. Hence the African was a subhuman! Aligned with the West, Christianity had endorsed the pervasive colonial discourse image of the African. By means of the bulls Dum Diversas (1452) - and - Romanus Pontifex (1455) - of Pope Nichloas V, the Catholic Church accorded the Portuguese kings "the right to dispossess and eternally enslave Mohammedans, pagans, and black peoples in general;" those kings had the "right to invade, conquer, expel, and fight Muslims, pagans, and other enemies of Christ wherever they may be" (Mudimbe 1988:45: Bimwenyi 1981a: $621-622)$. 
Okere (1996:20) discusses the enormous consequences of the role of Christianity on African Traditional Religion (ATR). He argues that the "monolith" that was Christianity abolished the mainstay of ATR - its pantheon of gods, goddesses, deities and divinities - insisting that they were idolatrous and devilish. The ministers of ATR - its priests and diviners - were no more than sorcerers; what is worse, its rites, rituals, and feasts were characterized as stinking orgies. African medicine was but unorthodox and magic, and no more! Not even our languages - they were considered "cacophonies of unspeakable gibberish. In sum, all was one irredeemable massa damnata(Okere1996:20-22). Accordingly, nothing African was good enough, and nothing good could be African. Without a history, culture and civilization, how human would the African be? Notoriously, Sir Hugh Trevor-Roper puts it poignantly. He writes,

May be in future there will be African history, but at the moment there is none. There is only the history of the white man in Africa. The rest is darkness and darkness is not a subject of history (Mazrui 2001:97-132)

The most arresting impact of Africa's negative history is, arguably, not the pillage and its various dimensions that the African had sustained. Rather it is its influence on the African psyche, the fact that the African was forced to perceive himself in the light of that negative history and, above all, came to accept that image as exquisitely his/hers. This is precisely what Ayittey (1992:5) considers the most detrimental effect of Africa's history. He writes, "It was probably this, rather ... that wrenched the heart from the inner psyche of blacks and assailed the very cultural soul of their existence." The humanity of the African was, thus, heavily contested. All through life, the African had it as his self-imposed task, to prove this humanity of his; or as Eboussi-Boulaga (1977) expresses it: "le dèsir d' attester une humanitè contestée."

This outlook has marked the African through and through. There is the competition to outdo one another in imitating the European. The inferior African aspires to be like the European. In terms of language, the African prefers the colonial masters' language. To speak any African language is a sign of inferiority. But 
one is a 'been-to' once one speaks one of the languages of the erstwhile colonizers. In admiration of the European, the African suffers identity crisis. The European is a "Bekee," "Oyibo," "Agbala." Whatever is not from the West is deemed inferior; and this includes what is roundly African; what the West does not produce! The values of the West become assumed as African values, while the core African values become rejected in preference to West. The dehumanization so affects the African that he/she is led, even, to deny himself or herself. This is the horrible aspect of the African condition. Of his aspect, Owomoyela writes,

Africans have not been the only people overrun by rampaging Europeans but Africans are unique in their belief that their future lies in becoming, in thought, speech, and habit, like their erstwhile colonizers" (Owomoyela 1987:37)

The African migrant is an embodiment of this negative outlook. And so, Europe still recalls the chained black slaves that once inhabited the dungeon. The African migrant is of the same stock. He/she is not any different from his/her ancestors. The high degree of surveillance of the European borders with Africa creates an impression of a war between Europe and Africa. Although all is done in the name of security, the history of the relationship between Africa and Europe of the early times are quite memorable. Typically European, only the students and highly skilled are permitted entry visas.

\subsubsection{The Europe of the Migrants' Dream}

"Once I reach Europe, I'll become rich." Chijioke, 30, a Nigerian, proudly announced to the delight of his young family and parents. Much as this statement betrays a speaker uniformed about Europe, it expresses the popular belief of nearly all African migrants to Europe. Like some other Nigerians, Chijioke had hoped to introduce himself into Europe - illegally. After long years of absence - eight years - he returned to Nigeria, ghostlike, totally spent and penniless. He did not go beyond Algeria! The source of 
his expectations lies in the presumably abundant, accessible job opportunities in Europe. Migrants, completely ignorant of the socioeconomic conditions prevalent in Europe, entertain the idea of Europe as an easy-to-live environment, a 'paradise on earth.' While they are not wrong that Europe is far better than their home countries, they merely have their heads in the clouds about Europe of their expectations - a nonexistent Europe. Their idea of Europe derives from the impact of the consumer society.

As a result of joblessness and poverty, the migrants perceive a ray of hope in the bright future that the European consumer society seems to extend to them. Tied in with the belief of a stupendously rich Europe is the conviction that they will receive a just wage for one's labours. Thus, in the service sector, cleaning jobs, stacking Supermarket shelves, menial jobs in the factories, and sometimes other odd jobs, which do not yield any meaningful avenues of livelihood in Africa, take on, for the migrants, an entirely new meaning allure.

rope.

Three cadres of African migrants - the highly skilled, the unskilled and the students - altogether seek entry visas. "Because we have no opportunities here in Africa," a migrant opined, "we must emigrate to Europe." One wonders, however, what job opportunities are accessible to skilled Africa migrants in Europe. Indeed, the highly skilled professionals like lawyers, members of the medical profession, clinical psychiatrists and counselors, IT workers, communications/media experts, computer experts, readily land an employment. Incidentally, African professionals, whose specialization runs along these lines, emigrate to Europe and the United State of America in droves. Thus, job opportunities offered become a constant pull that drains Africa of her best professionals. Some EU member states like Germany, United Kingdom, France, and the Netherlands have eased up their immigration policies to favour highly skilled migrants.

Job visas or the H-1B visas permit skilled migrants entries into the United States. In addition, the United States operate the widely known "America Lottery Scheme" that authorizes winners to sojourn in America. In 1990, the U. S. Senate voted 65, 000 visas for skilled migrants. By November, 2005, the number increased to 95,000, while in August 2006, the fixed number, 65, 000 was 
already attained (OECD,"Growing Competition for skilled Workers and Foreign Students. Available Online). Once did Australia plan to recruit skilled workers through the recruitment fairs in London, Berlin, Amsterdam, and Chennai in India. On its own part, New Zealand launched a new web site to lure her citizens elsewhere and other skilled workers seeking job opportunities in the country. Thus, some EU member states seek out skilled workers to accede to available job opportunities. Perhaps, the fast ageing labour force of those EU member states is one of the major reasons for this shift. But races other than Africans are desired!

Competition for foreign students has set in among the United States and EU member states. If foreign students are on demand, it is in the belief that they are the future skilled workers. While India and China provide the highest number of foreign students, their contributions may likely decline in future since their universities are rapidly developing. When the Canadian universities, for instance, modified their post-graduate programme to run for two years, instead of one, the number of foreign students, who enrolled, came to $17 \%$ (OECD, "Growing Competition for Skilled Workers and Foreign Students. Available Online). Despite the urgent desire of African youths to take advantage of the opportunity, which the European Labour Market presents, Europe superintends her borders in such a way as to create the impression that she is at way with Africa, hence the description, "fortress" Europe. Yet, Europe is not as glowing as the package presents her. One has, really, to set one's teeth on edge to succeed.

\subsubsection{The Idea of a "Fortress" Europe}

The conception of Europe fortified with ramparts and bulwarks gives an idea of an impenetrable territory. This design of Europe arose in the face of recent African migrations. The idea of a "fortress" has to do with the reinforced and harsh immigration laws, round the clock surveillance, concluded pacts, and a barbed-wire fence, several kilometers long, cordoning off the Spanish enclaves of Melila and Ceuta, the high powered SIVE (Integrated System of External Vigilance) installed along the fence as well as at the Strait 
of Gibraltar (Hein de Haas 2006). Despite renewed reinforcements of the fence, migrants successfully break through it. Several migrants have, however, been crushed to death in the attempt. Furthermore, the joint European Union (EU) border surveillance agency - the Frontex - avails itself of the most recent accessible technologies. With its intimidating huge arsenals of helicopters, airplanes, fast-moving patrol boats, and warships, Frontex creates the impression that Europe is at war with Africa - just to dissuade African migrants.

More than this, some EU member states have concluded several pacts with some African leaders to stem the flow of migrants. In July, 2006, at EU-AU (African Union) joint summit, the EU delegates pointedly made Africa-to-Europe migration a cardinal issue. Incidentally, EU successfully sold her carrot to North African countries like Libya and Morocco. Under the arrangement, EU would provide aids, financial support, etc. to these countries, which, in return, would step up their fight against migrants employing them as the last departure posts.

Because of their proximity to Africa, Southern EU member states are mostly affected. In addition to the agreements between EU and North African states, Southern states like Italy, Malta, and Spain, have equally concluded agreements with some African states. The Spanish government, for instance, sponsors advertisements in Senegalese Major Television Channels, emphasizing the risks and the dangers of Africa to Europe migration! In 2006, Spain and Morocco just as Italy and Libya did conclude pacts for a joint border surveillance. In 2003, Libya and Italy had previously entered into a pact about African migrants. The pact yielded immediate result for Libya. Italy's Prime Minister, Silvio Berlusconi, consequently, lobbied strongly among EU member states to lift the embargo under which Libya had groaned for nearly two decades following her suspected involvement in the Lockerbie bombing of the American Airliner. Libya has come under severe criticisms for playing the EU police in Africa. President Muammar al-Quadhafi is seen to cooperate closely with the International Organization for Migration (IOM).

Such pacts between EU and North African states have given rise to a general anti- immigration stance. Xenophobia has fuelled strict internal measures against illegal immigrants. In 2005, the 
Egyptian police killed 20 Sudanese refugees, who marched to protest the conditions in their improvised camps in Cairo. Mass border charges occur at Ceuta and Melila involving loss of lives. The Moroccan authorities have intensified internal anti-immigration campaigns, deporting migrants and abandoning some others on the Saharan desert.

A major error of North African states is their failure to distinguish 'transit' migrants and 'bogus' asylum seekers from refugees fleeing persecution and civil war. Refugees and asylum seekers rarely belong to 'transit' or bogus migrants. Whether transit or not, migrants are all found in the service sector, construction, agriculture, small scale business, e.t.c. Some intermarry with the North African citizens to gain residency papers; others pursue higher education to the same end. A good number become residents after failed attempts to secure a passage to Europe.

Since illegal immigrants enjoy no legal status, they constitute the butt of frequent police harassments, denial of legal justice, violation of personal rights, victims of violence and hideous killings. Consequently, immigration officials lump them together with "bogus asylum seekers" to deport them. Much less do the officials realize the enormous contributions of the apparently insignificant migrant group to the progress of a state's economic wheel. Despite the activities of the United Nations High Commissioner for Refugees, the Human Rights Watch, Amnesty International, Civil Rights Groups, Non-Governmental Organizations, North African states insistently deport genuine asylum seekers and refugees indiscriminately. Incidentally, some of these refugees and asylum seekers hail from war-torn horn of Africa, the area of the Great Lakes. Zimbabwe, and the violence-ridden Delta region of Nigeria.

\subsubsection{Education: Goods Europe Never Marketed to Africa}

If there was any European commodity, which Africans sought after the most, it was education. Incidentally, it was the sole commodity that Europe refused to market to Africa. At the end of the slave trade, African leaders were urgently desirous of this good. 
Isichei expresses poignantly the Africans' desire for education and the Europeans' rejection. She writes,

What the rulers of Delta $\{$ Africa $\}$ repeatedly asked to buy, Europe was never prepared to sell. This was basically knowledge, which could help them span the ever-widening technological gap between Africa and Europe. They \{Africans\} needed knowledge of production, and a market for its products. (Isichei 1977:54)

This view disproves the claim of the Nigerian journalist, George Lucky, winner of the European Commission's 2006 Lorenzo prize for reporting on Human Rights and Democracy, Lucky is credited with the view that Africans, just immediately prior to and even after independence, turned down offers of scholarship to study in the colonial masters' home countries.

In no other area of life in the West African sub-region did the European Christian Missions leave an indelible memory of their apostolate than in education. Added to the Christian Missions are two important factors that characterized the history of education in West Africa during the colonial era. Firstly, to operate to its full capacity, the colonial government and the giant European firms required the services of learned and numerate local labour force. Sourced from the colonies, they were not highly skilled. Yet, they creditably performed those duties that would have proved prohibitively costly were the colonial administration and the big firms to import trained manpower from their own country. Thus, such posts as the local artisans, secretaries, messengers, court clerks, school teachers, and other low cadre office personnel kept the colonial machine and its establishments continually functional. Secondly, the status, position and wages, which the educated enjoyed, made education a great attraction to Africans. Most significant was the immeasurable value that put the educated beyond the reach of drudgery and uninviting dullness of manual labour (Isichei 1977). The people's demand for literary education over against technological and vocational education betrayed the African preference of the prestigious white collar to blue collar jobs.

Although the colonial administration subsidized the Christian Mission forays into education, it demonstrated its 
reluctance and lack of interest to commit her resources to education even in its heydays (1914- 1945). In Nigeria, for instance, between 1924- 1925, the colonial government devoted $1.8 \%$ of its total expenditure to education, a slight increase of $0.8 \%$ over against $1.0 \%$ in 1918. Compare this figure with $17 \%$ accorded to education between 1951 - 1952, when colonialism had already collapsed and Nigerians were gradually replacing the colonial masters. In pre- and post- 1960, the Regional government had decidedly sunk $40 \%$ to extend the benefits of education to the hinterland. Because of poor funding and, perhaps, the refusal of parents, initially, to send their wards to school, the Missions education apostolate as well as a handful of pioneer schools in the mid- $19^{\text {th }}$ Century suffered some setbacks. British colonies held a good edge over against their French counterparts. Where, in 1939 , about $12 \%$ of the primary school age bracket in Nigeria enrolled for primary education, only $6 \%$ of the same age bracket in the Francophone West Africa attended primary school (Isichei 1977:256).

In all, education met with enormous difficulties in the colonial era. As a result, many pupils dropped out, Compare the situation of Senegal in 1960 when only about 2/3 of the entrants completed their primary school education. The craze for a university degree in England or the United States of America had become so overwhelming that even business merchants, like Omu Okwei of Ossomari (Ekejiuba 1966, 1967), traveled to England as did pioneer politicians like Sir Akanu Ibiam (Ottenberg 1992). Thus, George Lucky's claim that Africans early on refused the opportunity offered them to pursue a university degree in a foreign land is false through and through.

In post- World War 11 environment, Fourah Bay College in Sierra Leone, Achimota College in Ghana, and Yaba Collage in Nigeria were among the few institutions of higher education in West Africa (Isichei 1977:255-257). The paucity of higher institutions of learning demonstrated the colonial government's reluctance and illwill to promote veritable education in the colonies beyond the mastery of the three Rs. Such a stance was not unconnected with the colonial government's bid to hold down Africans, offering them 
subsidiary positions any way. The British colony, for instance, regulated the number of African doctors employed to work in government establishments (Isichei 1977). In a show of European racism, a Creole Oxford-educated graduate was forced back to England to pursue legal studies because he remained unemployed in his own country and at a time when doctors were in demand! At the time, only a handful of Europeans in the civil service held a university degree.

During the transition period, the Nigerian government, different Town Unions, and rich families offered scholarships to bright young people to pursue university education. In the 1950s, any bright student became a potential beneficiary of any of these scholarships. Obi Okonkwo, Achebe's hero in No Longer At Ease (Achebe 1983) was a beneficiary of such scholarships. Town Unions taxed their members "mercilessly" to put up befitting edifices to serve as primary schools. At the time, it appeared a default for West Africans to study for a university degree in the colonial master's home country or the United States of America. That was how some pioneer educationists in Nigeria studied overseas. Once the Igbo of South- eastern Nigeria perceived the relation of the Christian Mission apostolate and education, they converted to the Christian religion. Needless to say, there were genuine uneducated Christians like Joshua Hart and others. The second part of the work discusses migration flows, the difficulties and obstacles involved in the various means of acceding to Europe.

\subsubsection{Part Two: Migration Trajectories}

Africa-to-Europe migration catches the eyes for their numbers than for the risks that their trajectories involve. Alarmist reports hike the numbers of African immigrants and the European news media make them the butt of their journalism. Yet, by comparison with the overall migrant flows into Europe, African migrants, according to OECD (Organization for Economic Cooperation and Development) are quite minimal. While International Organization for Migration puts the number of African immigrants in Europe at 4.6 million in contrast to 890,000 in USA, the International Policy Institute suggests that illegal African immigrants are double the number - between 7 million and 8 
million. There is, thus, no agreement on the number of Africans resident in Europe. Of all African immigrants in Europe, two-thirds are North Africans, numbering higher than migrants from other regions in Africa. The sub-Saharans, mainly from Nigeria, Ghana and Senegal make their colonial powers their primary destinations in Europe. For their proximity to the Spanish enclaves and the Canary Islands, some thinkers focus on sea-crossings. Yet, the trans-Saharan trajectory is more perilous. Migrants also make use of airplanes, forged passports and fake visas.

If migrants gunned for mainland Spain as their primary destination in previous years, a shift has now occurred. Since 2006, Canary Islands have become their primary destination targets (Source: World Bank). Apparently, the numbers of Africans, who travel by sea, are a negligible fraction of 2.6 million African immigrants in 2004 (OECD in Hein de Haas). Of this number, 22,016 aim for Italy, of which 10,400 landed at Lampedusa, in contrast to 6,900 in $2005 ; 24,000$ between January and September 2006 made it to the Canary Islands, over against 4,772 in 2005 and 9,900 in 2002. Definitely, certain causes are behind the migration flows to Europe.

\subsubsection{Forces behind Africa-to-Europe Migrations}

Ever since the 9/11 terrorist bombing and attacks of targets in Europe, America, and Africa, security has gone atop the agenda of EU leaders. The reinforced EU anti-immigration policies, the high commitment of EU member states to fight crimes and their readiness to protect their interests the world over - all originated from possible threat to security. The forces behind Africa to Europe migration include: the Libyan pan-African policies, the rampant civil wars, the economic recession of West African sub-region (Hein de Haas 2006). When the embargo on Libya isolated her internationally, President Muammar al-Quadhafi reoriented Libya's foreign policy toward Africa. In addition, he relaxed Libya's immigration policies toward African immigrants and liberalized the Libyan labour market to absorb sub-Saharan Africans. Until the 2000 anti-immigration uprising, Libya was a haven for sub-Saharan migrants. Libya's 
immigration policies have, long since, taken a drastic turn against immigrants. Thus, a shift in the migratory trajectory occurred. Migrants, presently, tend westward to Algeria, Morocco and Tunisia (Hein de Haas 2006). The wars are another contributing factor.

Internecine and civil wars displace quite a number of Africans. The Congo basin hostilities threw up innumerable refugees as did the internecine Rwandan Hutu-Tutsi ethnic cleansing and genocide. Until the election of her first African Lady President, Liberia did not know any peace. Internal strife nearly consumed Sierra Leone (1991-2001) and Ivory Coast. The Sudanese religious civil war has turned Dafur into an international crisis. Of recent, the violenceprone Delta region of Nigeria leaves one with the impression of a country torn between national loyalty and her multiple ethnic identities. The political stand off in Zimbabwe causes, yet, another unrest and a source of concern. The pillage and extreme destruction in the wake of strife and violence, the near absence of reconstruction in the post-war years, the lack of social welfare security programmes for the poor - all compound the migrant problems in Africa. While these crises constitute a poor judgment on the political dispensation in Africa, their economic impact is most telling.

Nearly, all African states are listed among the HIPC (Highly Indebted Poor countries), where the poverty line is staggering. If Europe characterizes some of her poor population as the fourth world, in Africa, many families earn less than a dollar per day. The grim implications of a poverty-stricken population are all too well known: high rate of child/maternal mortality, widespread of HIV/AIDS disease, limited life expectancy, and a population that grows in leaps and bounds (2.83\% among African nations), outpacing the growth rate of the continent's economy. 84 million Nigerians, for instance, numbered among the 300 million HIPCs population, who thrive on less than a dollar (US \$0.65) a day (Pogge 2002:97-99; Stiglitz 2002:25; Wolf 2004:157-163). Yet, Nigeria has little or nothing to show after four decades of huge export earnings from oil (World Bank 1998:103). It seems then, that EU will fail in her bid to stem Africa to Europe migration if she does not address the economic and political forces that drive migrant Africans. Migration flows follow definite trajectories with attendant risks. 


\subsubsection{Migratory Trajectories and their Risks}

There are multiple means that Africans employ to reach Europe: by land, by sea and by air. Of these, none is as threatening as by land. We shall consider the trajectory by land. The migratory trajectory by land often traverses the Sahara and migrants employ the trans-Saharan routes.

\section{(a) By Land}

Until the trans-Saharan trade, West Africa did remain in relative isolation. Bounded in the North and South were two major monstrous obstacles - Sahara desert to the North and Atlantic ocean to the South. Trans-Saharan trade served dual purposes: trade and Muslims' pilgrimage to Mecca. Camels served as the means of transportation of goods across the desert. Commodities like slaves, salt, gold and other luxuries, traded at the peak of the trans-Saharan trade, proved important for the Sudanese as late as the $18^{\text {th }}$ Century. The flourishing trans-Saharan trade led to the growth of the West African empires of Mali, Songhai, and Ghana (Isichei 1982:44).

The route itself was perilous. Historical accounts of Caravans, who died because they had lost their track in the desert, abound. The scorching sun often dried up the oasis and the wells; brigands posed a serious threat to the caravans and the pilgrims (Isichei 1982:3-6). Hazardous, life-threatening dangers and unfriendly weather, the scotching heat in the day and the bitter cold in the night, the ferocious desert winds that buried the trucks and their wares, blizzard of wild beasts indicate the migrants have to brave all that to reach the chosen last departure post in North Africa. Though one may not be able to determine the how long it may take the migrant today, the trans-Saharan trajectory had taken the Caravans between two and three months to journey across the desert (Isichei 1982:6).

The migrants' destinations determine their last sojourn in North Africa - be that Libya, Algeria, Tunisia, or Morocco. To reach European Islands like Malta, or Italian coastal islands like Lampedusa, Pantalleria, or Sicily, migrants are more likely to travel by sea from Libya. West African coastal cities in such countries as Mauritania, Cape Verde and even Senegal are currently presenting 
alluring departure posts. Migrants make long and demanding journeys by sea to Canary Islands from these coastal cities in West Africa. From Morocco, migrants gain access to the Canary Islands. Not until xenophobia became diffused in the country did Morocco cease to play host to numerous West African migrants. Egypt and Algeria like other North African states serve as the last departure posts in the continent.

Networks of human-smugglers facilitate the migrants' journeys to Europe. Working in close collaboration with some disoriented and corrupt law enforcement agents, border patrol units, and immigration officials, these smugglers successfully introduce the migrants into Europe. This is, understandably, at a prohibitive cost to the migrants.

\section{(b) By Sea}

If, in the 1980s, the condition of the zodiacs, which conveyed African migrants to Europe, were deplorable, those fastmoving boats have enormously deteriorated since the 1990s. Battered, wooden rickety boats or zodiacs "are often filled out of sight of the shore." Sometimes $12 \mathrm{ft}$ or $40 \mathrm{ft}$ long, they are usually overcrowded with people. As many as 100 migrants crowd into a dilapidated boat meant to take only 50 people. Wooden boats, which take about 60 and 120 people, could be constructed at the cost of $\$ 3,500$ or 100,000 dalassis ("Gambia - new front in Migrant Trade," Available Online). In addition to its passengers, a boat holds other supplies to serve for a week's journey such as food, water, packs of first-aid, medicine, fuel, etc.

Really, these boatloads of migrants, sometimes, fail to reach their destinations. The Nigerian daily, in 2008 reported the ugly death by drowning of 60 Nigerian illegal immigrants off the Spanish coast of Motril. The boat was overcrowded. In 2003, for instance, one of such boats, carrying mainly Somali migrants, reached Italy with 15 survivors and 22 dead bodies, 15 of which were women and 7 children. The boat had stayed over a week at sea. And so, the migrants' supplies were depleted before a rescue ship spotted them. (www.travelafricanews.com). After Madame Yayi Bayan Diouf lost her only son to such risky attempts, she became self employed. Her task was to dissuade the fishermen in Dakar and migrants from undertaking such perilous journeys to uncertain destinations (Mother's Battle against Senegal Immigration.” BBC News Online). 
The residents of Canary Islands suffered shocks, in early 1990s the initial time they witnessed hunger-stricken, weak and disheveled African migrants. At the turn of the third Millennium, the plight of African migrants has become a regular occurrence for the residents of the Canary Islands. At present, they could tell accurately when a boatload of African migrants was expected at the beach. The tell-tale signs are unmistakable: Navy ship or boats, civil guards, Red Cross agents, and, sometimes, a helicopter for urgent cases. Other signs include tents, hospital beds, wheelchair e.t.c. Depending on one's chosen departure post, transportation fare is as high as from $\$ 800$ to $\$ 1,250$. The migrants exhibit a complete ignorance of the risks and threats to life involved. People-smugglers are not wont to inform their customers of the potential dangers of such travels: the boat could be turned back, run out of supplies, or even sunk.

To embark on the journey, migrants are determined to risk all; their families at home, parents, and friends. A Nigerian migrant to Spain, Nene, 28, directed his parents to "forget me. Count me dead and organize my funeral now because I am journeying to Europe." Unlike many, he successfully arrived in Spain after a month! Since some migrants take repayable loans, their families are held responsible should the migrant default. Others sell off their property, give up their jobs, businesses etc. to raise the transportation fare for the passage. One understands, then, the stoic determination of the migrants to succeed at all cost - a desperate attempt indeed. But for the changing perception of immigrants, are the attempts to emigrate worth the risks and threats to life involved?

\subsubsection{The Changing Perception of Immigrants' Standing in Africa}

Both in her life story and the manner of her death, Samura Adamu incarnates the African migrant. Originated from Northern Nigerian, Samura emigrated to Belgium in 1998. The Belgian government rejected her application for a refugee status, denied her a resident permit, and remanded her, like many others, in one of the refugee camps in Belgium - as an illegal immigrant. For the Belgian Government, she was a "bogus" asylum-seeker. Bogus asylum- 
seekers compound the problems of immigrants and immigration office. While the bogus asylum-seekers prevent genuine cases from getting the requisite attention, they permit false ones to be mistaken for true cases. Despite her story, the government was determined to deport Samura to her country, Nigeria.

A minor 16 years of age, Samura insisted that her family had concluded arrangements to give her in marriage, against her will, to an old man in Nigeria, an Alhaji perhaps. To escape the marriage, she fled both her family and her country, and sought respite in Europe. For all asylum-seekers, however important and credible their story, the greatest challenge is to prove that one is fleeing some persecution or a civil war. To do so, one necessarily engages the services of a seasoned legal practitioner. Since the Belgian government disbelieved Samura's story, despite a documentary about her life, aired on one of Belgium's principal television channels, the RTBF (Royale Télévision Belge Francaise), it prepared to deport her. The documentary, perhaps, was one of the means by which Samura fought her deportation.

Sandwiched between two policemen, Samura resisted all deportation attempts. At one time, through her cries and screams, she forced the passengers of the Belgium national Airliner, SABENA, bound for Nigerian, to disembark. Quarantined in Brussels, in the custody of the two policemen, Samura died after the policemen suffocated her with pillows to still her loud cries and screams. The policemen failed to force Samura into Nigeria-bound SABENA peacefully And so, she died, resisting attempts to return to her country, Nigeria.

Not until Samura's family rejected the deceased body of their daughter, demanding for explanations, did the Nigerian government change her attitude to the death of her citizen. Through the Nigerian Ambassador in Belgium, President Obasanjo's government forced an apology from the Belgian government. Some two years later, the two policemen were arraigned before a Belgian High Court, charged with the murder of Samura Adamu. It is unknown, however, whether they were convicted. Incidentally, Samura's death led to a cross-section of the Belgians - students, foreigners, urban dwellers, the youths and other NGOs demonstrating along the streets against the Belgian government of Jean-Luc Dehaene. 
Many African migrants' stories resemble Samura's. The story of two Senegalese, who hid themselves aboard SABENA is yet another horrific tale. Strikingly, their bodies were undiscovered until gradual decomposition set in. Only then were the bodies found, tucked away, with a letter, at the propeller wing of the aircraft. In their letter, written before their eventual death and found in their pockets, they lamented the inability of the Senegalese government to afford them good education. Really, the two Senegalese differed from other migrants, who seek job opportunities. The two students sought an opportunity to round off their education!

Since the economic down-turn of most African states, African consumer society has made successful immigrants a status symbol. This is the major problem. The successful ones are much less like Samura and the two Senegalese students, those drowned at sea, or yet again, those whom wild animals consumed alive in the course of the journey to Europe. Introducing oneself into Europe as an immigrant is half the story. One needs to battle one's way through the socio-economic and political odds of "fortress" Europe. Many immigrants have stayed on in Europe for donkey years, unwilling to return to African for one sole reason: they never eventually got rich. Criminal gangs recruit some of them. In this way, they become drug pushers. Unless forcefully deported, the disoriented African immigrants become imprisoned, killed, die-hard criminals, or chômeurs - jobless.

A handful turns out rich. They land good jobs, become selfemployed as musicians, proprietors of flourishing business enterprises, etc. Such immigrants help out their families at far-flung Africa through remittances. They finance community projects. On and off, they maintain a viable relationship with the home country. Even among these immigrants, who possess dual nationalities, one perceives some misguided others given to ostentatious lifestyle. African consumer society is quick enough to recognize them: they purchase titles, show off their wealth and compete for honours. Their mansions are outstandingly constructed and decorated. They command chains of dependents, some of whom are all too happy to live on the morsels from the master's table. One may not rule out 
hideous characters among these "been-tos." Since the economic decline of West African states, successful immigrant Africans have been a source of inspiration. In this way, they becloud numerous others that failed to make it. Many Africans seek to imitate them, unaware of their real life stories. If there exist no huge disparity in the living standards of much of Africa and Europe, it is doubtful that African immigrants will remain a powerful influence on popular psyche.

\subsection{Conclusion}

All through the paper, we have emphasized the pervasive role of the oppressive image that the African has of himself. Basically, this image is the aftermath of colonial discourse. Although many Africans are resident in Europe and contribute to its economy, the repressive image of the sub-human African still finds expression in the West. The worst deleterious effect of this discourse is the African internalization of the repressive outlook. This explains, not merely the attitude of Fortress Europe toward Africa, but also, the attitude of Africans vis-a-vis their lot. African consumer society is just a dimension of the negative portrayal of the African just as the status symbol, which it accords to immigrant Africans, is no more than an effect of harsh economic times in Africa, and ultimately, of her poor development. 


\subsubsection{References}

Achebe, C., No longer At Ease. London: Heinemann, 1960/1980.

Akpunonu, P.D., "Pastoral Care of Migrants and Refugees: A Call to Solidarity with Africa: Its Implications for Ministries and Services," (Available Online).

Ayittey, G.B.N., Africa Betrayed. New York: St. Martin's Press, 1991.

BBC News Online, "Key Facts: Africa to Europe Migration," 2 July, 2007, 21:05 GMT 22:05 UK

Binwenyi, O., Discourse théologique négro-africaine. Problèmes de fondements. Paris: Présence Africaine, 1981.

Carling, J., "Migration Control and Land Migrant Fatalities at the SpanishAfrican Borders," International Migrant Review, 2007.

Düvell, F., "Crossing the Fringes of Europe: Transit Migration in the EU's Neighborhood," Working paper No. 33, Centre on Migration, policy and Society (COMPSAA), Oxford: University of Oxford, 2006.

Dyer, E., Western Pennsylvania Proves to be a Land of Opportunity for African Migrants," Sunday, March 16, 2003 (Available Online)

Eboussi-Boulaga, F., "La Crise du Muntu, "Prèsence Africaine 1977.

Equiano, O., Equiano's Travels. P. Edwards (ed), Oxford: Heinemann, 1789/1967.

Fragues, P., "Arab Migration to Europe: Trends and Policies," International Migration Review 38(4), 2004, pp. 1371.

Fletcher, P., "Mirage of rich Europe Lures Job-Hungry Africa," BBC News Online, Dec., 05, 2007 at 05:07PM (Available Online)

Grabska, K., "Living on the Margins: the Analysis of the Livelihood Strategies of Sudanese Refugees with Closed Files in Egypt," Cairo: AUC/FMRS, 2005.

Haas, de Hein, "Trans-Saharan Migration to North Africa and the EU: Historical Roots and Current Trends," Nov.2006, (Available Online)

"Turning the Tide? Why Development instead of Migration Policies are bound to fail. IMI Working Paper 2. Oxford: International Migration Institute, University of Oxford (Available Online).

Hamoon, S., "Africa Transit Migration through Libya to Europe: the Human Cost," Cairo: FMRS/AUC, 13 ${ }^{\mathrm{TH}}$ May 2006.

Isichei, E., A History of Christianity in Africa: the Genesis of a Present. New Jersey: $\quad$ African World press, 1995.

., The Ibo People and the Europeans: The Genesis of a Relationship - to 1996. London: Faber and Faber, 1973. ., A History of the Igbo People. London: Macmillan, 1976. 
., History of West Africa Since 1800. London: Macmillan, 1977/1981. London: Faber and Faber, 1973.

Lucky, G., "Turning to Desert and Sea, African Migrants," (BBC News Online).

., "Stuck in Morocco, African Migrants Face a life of Hardship "May 2008 7:04 (BBC News Online)

.,African Migrants and Harsh Treatment in Africa and Europe, "Jan., 18, 2008 (BBC News Online)

Masolo, D. A., African Philosophy In Search of Identity. Bloomington: Indiana, 1994.

Montesquieu, C., The Spirit of Laws. Chicago: William Benton, 1952.

Mudimbe, V. Y., The Invention of Africa: Gnosis, Philosophy, and the Order of Knowledge. London: James Currey, 1988.

Ogude, S. E., "Introduction to the New Edition," in Equiano's Travels. P. Edwards (ed), Oxford: Heinemann, 1967/1996.

Oguejiofor, J. O., "Self Image and Development in Contemporary African Philosophy," Concordia (2003), pp.45-56.

Okere, T., "African Culture: the past and the Present as an Indivisible Whole," in Identity and Change. Nigeria Philosophical Studies 1. T. Okere (ed), Washington: Paideia, 1996, pp. 9-26.

Ottenberg, S., "Colonialism and the Individual: A Nigerian Life History," African Humanities 19 (1992), pp. 1-26.

Owmoyela, O., The African difference: Discourse on Africanity and the Relativity of Culture. Frankfurt a. M.:Peter Lang, 1996.

Pogge, T., World poverty and Human Rights. Cambridge: Polity Press, 2002.

Riccio, B., Talkin"' About Migration - Some Ethnographic Notes on the Ambivalent Representation of Migrants in Contemporary Senegal," Srichproben. Wiener Zeitschrift fuer kritische Afrikastudien Nr. 8/2005, 5. Jg

Sy, T., "Mother's Battle against Senegal Migration," (BBC News, Dakar online)

Stiglitz, J., Globalization and Its Discontents. London.

Tempels, P. F., Bantu Philosophy, Prèsence Africaine. 1959/1969.

Winter, J., “African Migrants' Elusive Dream,” (BBC News Online)

Wolf, M., Why Globalization Works. New Haven Conn: Yale University Press, 2004

World Bank, Assessing Aid: What Works. What Doesn't, and Why. New York: Oxford University Press, 1998. 